
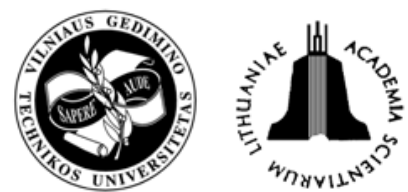

\title{
AUTOMOBILE BRAKING AND TRACTION CHARACTERISTICS ON THE DIFFERENT ROAD SURFACES
}

\author{
Edgar Sokolovskij \\ Dept of Automobile Transport, Vilnius Gediminas Technical University, \\ J. Basanavičiaus g. 28, LT-03224 Vilnius, Lithuania.E-mail: Edgar.Sokolovskij@ti.vgtu.lt
}

Received 16 May 2007; accepted 10 September 2007

\begin{abstract}
The present article depicts the results of the investigation into automobile braking parameters and traction characteristics on the different road surfaces. The results of the investigation into automobile braking (the automobile deceleration and coefficient of traction), while braking in winter conditions, i.e. on ice and snow, are presented. The values of deceleration of the automobile while braking on various non-typical surfaces, on the asphalt, covered with the motor oil or resin, while driving across the petrol spot, and on other surfaces of the road, are presented. Such data are necessary while modelling the automobile's movement in various road conditions and while carrying out the examination of traffic accidents.
\end{abstract}

Keywords: automobile, braking parameters, deceleration, coefficient of traction, different road surfaces.

\section{Introduction}

The automobile is driven along various road surfaces. Sometimes the situation occurs, when there are places on the road, fit for traffic, where the coefficient of traction of the surfaces with the wheels is different. For example, the stripe of the road, fit for traffic, is covered with sand or slush, is coated with ice in certain places, etc. Further the values of deceleration of automobiles and traction coefficients of their wheels while braking on different road surfaces in each definite case will be submitted. Such data are necessary while analysing and modelling the automobile's movement in various road conditions, while restoring the course of traffic accidents and while carrying out the examination of traffic accidents [1-4].

\section{Automobile decelerations and traction characteristics, while braking in winter conditions}

The tests were carried out on horizontal surface of the asphalt road, where there was no traffic [4-5]. Measurements were taken with the help of an electronic device, which measures deceleration, i.e. the decelerometer VZM 100. The automobiles were in a good technical condition and equipped with the factory (non-substituted) brake system. They were equipped with the tyres of the size, which is recommended for this particular type of the model. The air pressure of the tyres was nominal for the definite model of the automobile and its load.

Tests of braking of the automobiles were carried out in winter conditions, i.e. on ice and snow. In our case these were the automobiles FORD ESCORT (equipped
Table 1. Decelerations of the automobiles in winter conditions

\begin{tabular}{|l|c|c|}
\hline $\begin{array}{c}\text { Surface of } \\
\text { the road, fit } \\
\text { for traffic }\end{array}$ & $\begin{array}{c}\text { Average deceleration } \\
\text { of the automobile, } \\
\text { equipped with ABS, } \\
\mathrm{m} / \mathrm{s}^{2}\end{array}$ & $\begin{array}{c}\text { Average deceleration } \\
\text { of the automobile } \\
\text { without } \mathrm{ABS}, \mathrm{m} / \mathrm{s}^{2}\end{array}$ \\
\hline Ice & 2.0 & 1.8 \\
\hline Snow & 2.6 & 3.0 \\
\hline
\end{tabular}

with ABS) and FORD SIERRA (without ABS). The obtained results are presented in Table 1.

In the course of investigation it was shown that a slightly higher deceleration was typical for the automobile, equipped with $\mathrm{ABS}$, in the course of its braking on ice.

A bit different results were obtained while braking the automobiles, equipped with ABS and without it, on snowy surface of the road, fit for traffic. In this case a slightly higher deceleration was typical for the automobile without ABS. Such unexpected results can be explained by the fact that blocked wheels of the automobile without ABS contact with wet surface of asphalt road, covered with a thin layer of snow, thus stipulating the deceleration increase. Besides, the blocked wheels push and thicken the snow in front of them. Thus, the area of wheel bearing increases and the effect, similar to braking of the automobile on the soft surface (for example, the soft soil) shows itself [6].

The wheels of the automobile, equipped with ABS, remain unblocked. Thus, they do not contact with wet surface of asphalt road and the deceleration is lower. However, it should be stressed that, in any case, including the case relating to braking of the automobile on the 
Table 2. Coefficient of traction on snow and ice

\begin{tabular}{|l|c|c|}
\hline \multicolumn{1}{|c|}{ Road surface } & More detailed description of the surface condition & Coefficient of traction $\phi$ \\
\hline Battered snow & $\begin{array}{c}\text { Snow, battered by automobiles, which does not make the pounded } \\
\text { layer of snow and ice }\end{array}$ & $0.24-0.37$ \\
\hline Non-battered snow & $\begin{array}{c}\text { Snow, which has just fallen on the asphalt and which is not } \\
\text { battered by the wheels of automobiles - the first driving }\end{array}$ & $0.15-0.42$ \\
\hline $\begin{array}{l}\text { Snow and ice, covered with the } \\
\text { snow, which has just fallen }\end{array}$ & $\begin{array}{c}\text { Battered snow and ice, covered with the layer of snow (thickness - } \\
\text { up to 10 cm), which has just fallen and is not battered }\end{array}$ & $0.18-0.45$ \\
\hline $\begin{array}{l}\text { Snow and ice, mixed with sand } \\
\text { and slush }\end{array}$ & $\begin{array}{c}\text { Battered snow and ice, mixed with sand and slush, the particles of } \\
\text { which make 3-6 mm in diameter }\end{array}$ & $\begin{array}{c}\text { Depending upon the } \\
\text { quantity of slush } \\
\text { (little - much) } \\
0.15-0.45\end{array}$ \\
\hline Snow and ice & Entire layer of snow, battered to the extent of the icy surface & $0.12-0.39$ \\
\hline Snow and ice before crossroads & $\begin{array}{c}\text { Snow, which at first was melted by the motors of the standing } \\
\text { automobiles and then frozen up to the smooth surface }\end{array}$ & $0.09-0.22$ \\
\hline Deep snow & $\begin{array}{c}\text { Deep and non-touched snow when the automobile "seats itself at } \\
\text { the bottom", however, it does not stick }\end{array}$ & $0.92-0.95$ \\
\hline $\begin{array}{l}\text { Dry asphalt in winter } \\
\text { conditions }\end{array}$ & Dry asphalt (uncovered with anything) in winter conditions & $0.59-0.72$ \\
\hline Asphalt, covered with hoar-frost & $\begin{array}{c}\text { White cover on the asphalt, which is observed by the driver and } \\
\text { easily recognized as hoar-frost }\end{array}$ & $0.48-0.58$ \\
\hline Smooth ice & $\begin{array}{c}\text { Thick layer of frozen water, non-infringed with prickles and } \\
\text { chains }\end{array}$ & $\begin{array}{c}\text { Thick non-infringed layer of frozen water, infringed with the } \\
\text { wheels, equipped with steel chains }\end{array}$ \\
\hline Ice and tyres with chains & $\begin{array}{c}\text { Thick entire ice layer, looking as a wet, black stretch of the road, } \\
\text { which is fit for traffic, which is non-easily noticed by the driver }\end{array}$ & $0.054-0.19$ \\
\hline "Black" ice & \multicolumn{1}{|c|}{\begin{tabular}{c}
$0.12-0.18$ \\
\hline
\end{tabular}} \\
\hline
\end{tabular}

snow (though in this case the deceleration of the automobile, equipped with ABS, was a bit smaller), the ABS distinguishes by a significant positive influence upon the automobile operation, as the possibility to steer it remains. This is very important for traffic safety as most of the traffic accidents occur because of the absence of the possibility to operate the automobile.

However, diversity of the road surfaces is vast in winter conditions. For example, the statement that the stretch of the road, fit for traffic, is covered with snow points to almost nothing. It may mean the snow, which has just fallen; the snow, which is battered; the snow, which is covered with the layer of ice; the battered snow, which is strewn with the sand, etc. Accordingly the coefficient of traction of the wheels with the road surface is different in each case.

Some values of deceleration in winter conditions are submitted in Table 1. However, sometimes the cases, which have not been described in the literature, occur in practice $[4,7,8]$. The values of the coefficient of traction on the snow and ice are submitted in Table 2. These values pertain to the universal tyres.

It is a frequent case, when the values of the coefficient of traction, which are submitted in the literature for such cases, differ or their limits, which are specified, are too wide. It is like this because the conditions of investigation, the type of tyres, the model, etc. significantly influence the obtained values. It is known that the snow and ice change their qualities depending upon the temperature, thus, this fact influences the obtained results as well.

\section{Automobile decelerations, while braking on the different road surfaces}

Sometimes the situation occurs, when the automobiles are braking on the non-typical surfaces or there are places on the road, fit for traffic, where the coefficient of traction of the surfaces with the wheels is different. Such cases are described in the literature [4, 7-14].

The values of deceleration of automobiles while braking along various non-typical surfaces are submitted in Table 3 .

Table 3. Values of deceleration of the automobile while braking on various non-typical surfaces

\begin{tabular}{|l|c|}
\hline \multicolumn{1}{|c|}{ Road surface } & Deceleration \\
\hline Battered soil & $(0.6-0.65) g$ \\
\hline Grass & $(0.35-0.54) g$ \\
\hline Sand, gravel (loose - pounded) & $(0.4-0.7) g$ \\
\hline Edge of the road (non-asphalted) & $(0.35-0.4) g$ \\
\hline Slush on the wet surface & $(0.2-0.3) g$ \\
\hline Remark: $g$ is acceleration of gravity, $\mathrm{m} / \mathrm{s}^{2}$. \\
\hline
\end{tabular}

Sometimes very unusual surfaces, which are not typical of the normal traffic, occur. However, practically (for example, while carrying out the examination of traffic accidents), such data, which may be applied towards single separate cases, are necessary as well. Thus, Table 4 reflects deceleration of the automobile with ABS while braking on the wet asphalt, which is covered with grain. Deceleration was measured exactly on the wet asphalt because, from the point of view of the traffic safety, such 
case is more dangerous because at that time a significant reduction of deceleration is observed (similar to braking on the asphalt, which is covered with slush).

Table 5 reflects deceleration of the automobile while braking on the asphalt, which is covered with motor oil or resin.

Interesting results have been obtained while investigating deceleration of the automobile while braking on the stretch of the road, fit for traffic, on which the petrol was spilt. The results of investigation are submitted in Table 6.

Dependence of deceleration upon the time (when the surface is drying) was investigated. The results of investigation prove that the spilt petrol immediately starts to react chemically with the asphalt and creates a very slippery surface, which later dries and acquires the previous coefficient of traction. The surface of the stretch of the road, fit for traffic, being wet with water in the place, where the petrol was spilt, has a bit smaller coefficient of traction.

The investigation proves that deceleration of the automobile with the up-to-date tyres when the wheels slide in the transversal direction is close to the value of deceleration while braking on the same surface.

\section{Conclusions}

1. After the experimental investigation in winter conditions, it was proved that braking of the automobile, equipped with $\mathrm{ABS}$, on ice is more efficient (by approximately $10 \%$ ). Braking of the automobile without ABS on snow-covered surface of the road is more efficient (by approximately $13 \%$ ) because in this case the blocked wheels of the automobile contact with wet surface of asphalt road, push and thicken the snow in front of them.

2. The automobile decelerations and traction characteristics, while braking in winter conditions, are presented in Tables 1 and 2. The values of the coefficient of traction for such cases, differ or their limits, which are specified, are too wide. It is like this because the conditions of investigation, the type of tyres, the model, etc. significantly influence the obtained values. The snow and ice change their qualities depending upon the temperature, thus, this fact influences the obtained results.

3. The values of deceleration of the automobile while braking on various non-typical surfaces, on the asphalt, covered with the motor oil or resin, while driving across the petrol spot, and on other surfaces of the road, are presented in Tables 3-6.

4. Such data are necessary while modelling the automobile's movement in various road conditions and while carrying out the examination of traffic accidents. There is a possibility to model the automobiles' movement and to restore the course of the traffic accidents more precisely while carrying out the examination of the traffic accidents.
Table 4. Deceleration of the automobile with ABS while braking on the wet asphalt surface, covered with the layer of grain

\begin{tabular}{|l|c|}
\hline \multicolumn{1}{|c|}{ Road surface } & Deceleration, $\mathrm{m} / \mathrm{s}^{2}$ \\
\hline $\begin{array}{l}\text { Wet asphalt, covered with a "dry" } \\
\text { layer of grain }\end{array}$ & 3.3 \\
\hline $\begin{array}{l}\text { Wet asphalt, covered with a "wet" } \\
\text { layer of grain }\end{array}$ & 2.9 \\
\hline
\end{tabular}

Table 5. Deceleration of the automobile while braking on the asphalt, covered with the motor oil or resin

\begin{tabular}{|l|c|}
\hline \multicolumn{1}{|c|}{ Road surface } & Deceleration \\
\hline Wet rough asphalt, on which oil is spilt & $(0.25-0.3) g$ \\
\hline Wet smooth asphalt, on which oil is spilt & $(0.05-0.12) g$ \\
\hline Resin is spilt on the asphalt & $(0.5-0.64) g$ \\
\hline
\end{tabular}

Table 6. Deceleration of the automobile while driving across the petrol spot

\begin{tabular}{|c|c|c|}
\hline $\begin{array}{l}\text { Description of } \\
\text { the surface and } \\
\text { driving } \\
\end{array}$ & Time & Deceleration \\
\hline $\begin{array}{l}\text { Driving along } \\
\text { the dry asphalt } \\
\text { without the spot of } \\
\text { petrol }\end{array}$ & - & $0.8 g$ \\
\hline $\begin{array}{l}\text { Driving across the } \\
\text { spot of petrol }\end{array}$ & $\begin{array}{c}\text { After } 10 \mathrm{~s} \text { from the } \\
\text { moment of spilling } \\
\text { the petrol }\end{array}$ & $0.22 g$ \\
\hline $\begin{array}{l}\text { Repeated driving } \\
\text { across the trace }\end{array}$ & $\begin{array}{l}\text { After } 3 \text { min since } \\
\text { the spot became } \\
\text { dry }\end{array}$ & $\begin{array}{c}(0.60-0.34) g \\
\text { (according to } \\
\text { the direction of } \\
\text { driving) }\end{array}$ \\
\hline $\begin{array}{l}\text { Repeated driving } \\
\text { across the trace }\end{array}$ & $\begin{array}{l}\text { After } 6 \text { min since } \\
\text { the spot became } \\
\text { dry }\end{array}$ & $\begin{array}{l}(0.80-0.54) g \\
\text { (according to } \\
\text { the direction of } \\
\text { driving) }\end{array}$ \\
\hline $\begin{array}{l}\text { Driving across the } \\
\text { non-driven spot }\end{array}$ & $\begin{array}{c}\text { After } 9 \text { min since } \\
\text { the spot became } \\
\text { dry }\end{array}$ & $0.56 g$ \\
\hline $\begin{array}{l}\text { Driving across } \\
\text { completely dried } \\
\text { spot }\end{array}$ & $25 \mathrm{~min}$ & $0.80 g$ \\
\hline $\begin{array}{l}\text { Driving on the wet } \\
\text { asphalt without } \\
\text { the spot }\end{array}$ & - & $0.55 g$ \\
\hline $\begin{array}{l}\text { Driving across the } \\
\text { spot of petrol on } \\
\text { the wet asphalt }\end{array}$ & $\begin{array}{l}\text { After } 50 \text { min since } \\
\text { the moment of } \\
\text { spilling }\end{array}$ & $0.45 g$ \\
\hline
\end{tabular}

\section{References}

1. DANNER, M.; HALM, J. Technical analysis of road accidents (Technische Analyse von Verkehrsunfällen). Eurotax (International) AG CH-8808 Pfäffikon, 1994. 570 p. (in German).

2. LUKOŠEVIČIENĖ, O. The accident analysis and simulation: monograph (Autoịvykiu analizė ir modeliavimas: monografija). Vilnius: Technika, 2001. 244 p. (in Lithuanian).

3. ILARIONOV, V. A. Examination of road traffic accidents (Экспертиза дорожно-транспортных происшествий). Moscow: Transport, 1989. 254 p. (in Russian).

4. SOKOLOVSKIJ, E. Investigation into interaction of the wheel with the road and its elements in the context of examination 
of traffic accidents. Doctoral Dissertation (Rato sąveikos su keliu ir jo elementais tyrimai eismo įvykiu ekspertizès kontekste. Daktaro disertacija). Vilnius: VGTU, 2004. 147 p. (in Lithuanian).

5. SOKOLOVSKIJ, E. Experimental investigation into the braking process of automobiles. Transport, 2005, Vol. XX, No 3, p. 91-95.

6. ZWICKER, K. P. Private communication: coefficient of friction testing on snow-covered asphalt. Pleasantville, Nova Scotia, 1995.

7. UNARSKI, J.; WACH, W.; ZĘBALA, J. Receivable values of friction coefficient in different specific conditions. In Proceedings of the 7-th Conference "Problems of reconstruction of road accidents", held in Cracow on 11-12 September, 2000, p. 255-265 (in Polish).

8. MARTIN, D. P.; SCHAEFER, G. F. Tire-road friction in winter conditions for accident reconstruction. Society of Automotive Engineers Inc., SAE Paper 969657.

9. CHRISTOFFERSON, S.; JARZOMBEK, M.; WALLINGFORD, J. Deceleration factors on off-road surfaces applicable for accident reconstruction. Society of Automotive Engineers Inc., SAE Paper 950139.

10. FRICKE, L. Traffic accident reconstruction. Northwestern University Traffic Institute, 1990.

11. LIMPERT, R. Motor vehicle accident reconstruction and cause analysis. The Michie Company, 1989.

12. COLLINS, J. C. Accident reconstruction. Charles Thomas, Springfield, 1979.

13. ANIOŁA, M.; KUREK, J.; LEWANDOWSKI, A.; WARSZCZYNSSKI, J. Braking of the automobile in conditions of danger for safety through change of the surface state. In Proceedings of the 7-th Conference "Problems of reconstruction of road accidents", held in Cracow on 11-12 September, 2000, p. 219-227 (in Polish).

14. NAVIN, F.; MACNABB, M.; NICOLETTI, C. Vehicle traction experiments on snow and ice. Society of Automotive Engineers Inc., SAE Paper 960652. 